\title{
Características fermentativas, composição química e fracionamento de carboidratos e proteínas de silagem de capim-elefante emurchecido ou com adição de torta de mamona
}

\author{
Fermentation characteristics, chemical composition and \\ fractionation of carbohydrates and crude protein of silage of \\ elephant grass wilted or with addition of castor bean meal
}

\author{
Leandro Sampaio Oliveira Ribeiro ${ }^{1 *}$; Aureliano José Vieira Pires ${ }^{2}$; \\ Gleidson Giordano Pinto de Carvalho ${ }^{3}$; Mara Lúcia Albuquerque Pereira \\ Alana Batista dos Santos ${ }^{1}$; Leone Campos Rocha ${ }^{5}$
}

Resumo

O experimento foi conduzido para avaliar os teores de nitrogênio amoniacal, potencial hidrogeniônico, perdas decorrentes do processo fermentativo, composição química, fracionamento de carboidratos e de proteínas de silagens de capim-elefante emurchecido, ou não, contendo torta de mamona. $\mathrm{O}$ delineamento experimental adotado foi o inteiramente casualizado, com cinco tratamentos e quatro repetições: capim-elefante emurchecido; capim-elefante não emurchecido; capim-elefante mais torta de mamona (6\%); capim-elefante mais torta de mamona (12\%) e capim-elefante mais torta de mamona (18\%). o coproduto foi adicionado com base na matéria natural. Adotou-se uma massa específica de $600 \mathrm{~kg} / \mathrm{m}^{3}$. A silagem contendo $18 \%$ de torta de mamona apresentou maior $(\mathrm{P}<0,05)$ valor de $\mathrm{pH}$ $(4,8)$. Teor elevado de nitrogênio amoniacal foi verificado para a silagem de capim não emurchecido $(12,8 \% \mathrm{~N}$-total). A torta de mamona foi eficiente em reduzir $(\mathrm{P}<0,05)$ as perdas por efluente e total, proporcionando maior índice de recuperação da matéria seca. Além disso, mostrou-se eficiente em aumentar $(\mathrm{P}<0,05)$ os teores de matéria seca, matéria mineral, proteína bruta e lignina. Já a matéria orgânica, nitrogênio insolúvel em detergente ácido, nutrientes digestíveis totais, fibra em detergente neutro, fibra em detergente ácido, celulose e carboidratos totais diminuíram $(\mathrm{P}<0,05)$ com a inclusão da torta de mamona. Para o fracionamento de carboidratos, não se verificou diferença $(\mathrm{P}>0,05)$ entre as silagens aditivadas para as frações $A+B 1, B 2$ e C. Para o fracionamento de proteína, as frações $A$ e $C$ diminuíram $(\mathrm{P}<0,05)$ com o aumento de inclusão da torta de mamona, diferentemente, da fração $\mathrm{B} 1+\mathrm{B} 2$ que se elevou. A torta de mamona destaca-se como um bom aditivo na ensilagem de capim-elefante, por reduzir a umidade e melhorar o perfil fermentativo das silagens, além disso, foi eficiente em incrementar o teor de proteína bruta das silagens, principalmente quando se utiliza a dose de $18 \%$.

Palavras-chave: Biodiesel, coprodutos, Pennisetum purpureum, Ricinus communis L.

\footnotetext{
${ }^{1}$ Mestres em Zootecnia, Programa de Pós-Graduação em Zootecnia, UESB, Itapetinga, BA. E-mail: leosampaio-zoo@hotmail.com; alanasantos10@hotmail.com

${ }^{2}$ Prof. Pleno, Dept ${ }^{\circ}$ de Tecnologia Rural e Animal, DTRA, UESB, Itapetinga, BA. Pesquisador do CNPq. E-mail: aurelianojvp@ yahoo.com.br

${ }^{3}$ Prof. do Dept ${ }^{\circ}$ de Produção Animal, UFBA, Salvador, BA. E-mail: gleidsongiordano@yahoo.com.br

${ }^{4}$ Prof $^{\mathrm{a}}$ Plena, Dept ${ }^{\mathrm{o}}$ de Estudos Básicos Instrumentais, DEBI, UESB, Itapetinga, BA. E-mail: marauesb@yahoo.com.br

${ }^{5}$ Discente do Curso de Graduação em Zootecnia, UESB, Itapetinga, BA. E-mail: leonezootecnia@hotmail.com

* Autor para correspondência
} 


\begin{abstract}
The experiment was conducted to evaluate the concentrations of ammonia nitrogen, hydrogen potential, the losses of deriving the fermentative process, nutritional value, the fractioning of carbohydrates and protein the elephant grass silage wilted or not containing castor bean meal. The experimental design was completely randomized, with five treatments and with four replications: elephant grass wilted; elephant not wilted; elephant grass more castor bean meal (6\%); elephant grass more castor bean meal $(12 \%)$ and elephant grass more castor bean meal $(18 \%)$, the coproduct was added with base on natural matter. We adopted a specific mass of $600 \mathrm{~kg} / \mathrm{m}^{3}$. The silage containing $18 \%$ castor bean meal showed higher $(\mathrm{P}<0.05) \mathrm{pH}(4.8)$. High level of ammoniacal nitrogen was observed in the silage grass not wilted $(12.8 \% \mathrm{~N}$-total). The castor bean meal was effective in reducing $(\mathrm{P}<0.05)$ losses to by effluent and total, providing a higher rate of recovery of dry matter. Also, was efficient in increasing $(\mathrm{P}<0.05)$ the levels of DM, ash, crude protein e lignin. Already for organic matter, acid detergent insoluble nitrogen, total digestible nutrients, neutral detergent fiber, acid detergent fiber, cellulose and total carbohydrate decreased $(\mathrm{P}<0.05)$ with increasing doses of the castor bean meal. For the carbohydrate fractioning, there was no difference $(\mathrm{P}>0.05)$ among the silages with additives for fractions $\mathrm{A}+\mathrm{B} 1, \mathrm{~B} 2$ and $\mathrm{C}$. For the protein fractioning, the fractions $\mathrm{A}$ and $\mathrm{C}$ decreased $(\mathrm{P}<0.05)$ with increase of the inclusion of castor bean meal, differently, of the fraction $\mathrm{B} 1+\mathrm{B} 2$ which increased. The castor bean stands out as a good additive in silage of elephant grass to reduce moisture and improve the fermentation characteristics of silages also was effective in increasing the protein value of silages, especially when using the dose $18 \%$.

Key words: Biodiesel, coproduct, Pennisetum purpureum, Ricinus communis L.
\end{abstract}

\section{Introdução}

Uma das principais gramíneas tropicais utilizadas na produção de silagem é o capim-elefante, por apresentar elevada produtividade de matéria seca (80 toneladas MS/ha/ano) (CARVALHO et al., 2008). Entretanto, no momento ideal para ensilagem, quando o capim-elefante apresenta elevado valor nutritivo, normalmente, o teor de umidade é elevado (VILELA, 1990), podendo variar entre 82 a $78 \%$ de umidade e assim, pode ocasionar riscos a produção de silagem, devido à maior propensão e proliferação de microrganismos indesejáveis.

Diante das barreiras que ocorrem ao se utilizar forragem com alta umidade e baixos teores de carboidratos solúveis, Rodrigues et al. (2005) sugeriram que a inclusão de uma fonte de carboidratos solúveis ao capim-elefante, durante a ensilagem, pode melhorar, consideravelmente, a qualidade final das silagens. Assim, pesquisas vêm sendo realizadas com a finalidade de avaliar alguns aditivos que possam beneficiar o processo fermentativo de silagens de capim-elefante, como a adição do farelo de cacau (CARVALHO et al., 2007); o farelo de mandioca (PINHO et al., 2008); a casca de café, farelo de cacau e farelo de mandioca (PIRES et al., 2009), que são absorventes de umidade e podem incrementar o teor de carboidratos solúveis, além da prática do emurchecimento (FERRARI JÚNIOR; LAVEZZO, 2001).

Entre os aditivos utilizados, atualmente destacase os coprodutos do biodiesel e, dentre eles, a torta de mamona, pois, diferentemente da soja, girassol, amendoim e outras oleaginosas, a mamona não é destinada à alimentação humana, logo, não possui a concorrência deste mercado (PIRES et al., 2004). Além da torta de mamona ser gerada em grandes quantidades, como se constata no trabalho desenvolvido por Almeida et al. (2006), verificaram que com $100 \mathrm{~kg}$ de mamona obtém-se $75 \mathrm{~kg}$ de semente e $25 \mathrm{~kg}$ de casca. Da semente extrai-se o óleo, que corresponde a $50 \%$ em óleo e $50 \%$ é a torta, tornando o coproduto menos oneroso pelo volume gerado.

Objetivou-se avaliar as perdas decorrentes do processo fermentativo, bem como o valor nutritivo da silagem de capim-elefante emurchecido ou silagem de capim-elefante não emurchecido contendo torta de mamona $(6 \% ; 12 \%$ e $18 \%$ na 
matéria natural).

\section{Material e Métodos}

O experimento foi conduzido no Laboratório de Forragicultura e Pastagem, pertencente à Universidade Estadual do Sudoeste da Bahia, Campus Juvino Oliveira, localizada no município de Itapetinga, Estado da Bahia.

Como material para ensilagem, foi utilizado o capim-elefante (Pennisetum purpureum Schum. cv. Napier) proveniente de uma capineira implantada na própria Universidade. No momento do corte, o capim apresentou $1,8 \mathrm{~m}$ de altura, após 60 dias de rebrota, com 22,2\% de matéria seca, sendo picado em picadoura estacionária com tamanho de partículas variando entre 1 a $2 \mathrm{~cm}$. Imediatamente após a picagem foi homogeneizado, aditivado com a torta de mamona, conforme os tratamentos na ensilagem.

A torta de mamona foi detoxicada, utilizando solução de $\mathrm{Ca}(\mathrm{OH})_{2}$ (1 kg para $10 \mathrm{~L}$ de água), na quantidade de $60 \mathrm{~g}$ de $\mathrm{Ca}(\mathrm{OH})_{2} / \mathrm{kg}$ de farelo, na base da matéria natural, conforme recomendado por Oliveira (2008).

Para obtenção da silagem de capim-elefante emurchecido, o capim colhido foi deixado no campo, após 8 horas de exposição ao sol, sem revolvimento, posteriormente foi picado e ensilado.

O delineamento experimental adotado foi $\mathrm{o}$ inteiramente casualizado, com cinco tratamentos e quatro repetições, como a seguir: capim-elefante emurchecido; capim-elefante não emurchecido; capim-elefante não emurchecido + torta de mamona (6\%); capim-elefante não emurchecido + torta de mamona (12\%) e capim-elefante não emurchecido + torta de mamona (18\%). O coproduto foi adicionado com base na matéria natural (peso/ peso). Com base na matéria seca, as doses 6, 12 e $18 \%$ corresponderam, respectivamente, às doses 20,$8 ; 35,9$ e $47,4 \%$.
Para produção das silagens, composição química Tabela 1, foram utilizados silos experimentais de cloreto de polivinila - PVC, com dimensões de $50 \mathrm{~cm}$ de altura por $10 \mathrm{~cm}$ de diâmetro, providos de tampa com válvula de Bunsen com areia e tela no fundo, previamente pesados para captação de efluente das silagens de capim-elefante. As avaliações de perdas foram realizadas por ocasião da abertura dos silos.

O material foi compactado, adotando-se uma massa específica de $600 \mathrm{~kg} / \mathrm{m}^{3}$, correspondendo a $2,0 \mathrm{~kg}$ de matéria natural por silo. Posteriormente, os silos foram vedados, pesados e ficaram armazenados por 60 dias. Após o período de armazenamento, os silos foram novamente pesados para se estimar as perdas por gases (PG), perdas por efluente (PE), perda total (PT) e o índice de recuperação de matéria seca (IRMS) nas silagens mediante equações propostas por Jobim et al. (2007).

Parte da silagem foi utilizada para análise do nitrogênio amoniacal $\left(\mathrm{N}-\mathrm{NH}_{3}\right)$ e potencial hidrogeniônico $(\mathrm{pH})$, determinados logo após abertura dos silos. O teor de $\mathrm{N}_{-} \mathrm{NH}_{3}$, em percentagem do nitrogênio total, foi estimado segundo Cunniff (1995). Já o pH foi medido utilizando-se potenciômetro digital.

As amostras coletadas em cada silo foram devidamente identificadas, acondicionadas e armazenadas em freezer a uma temperatura de menos $10^{\circ} \mathrm{C}$. Posteriormente, em momento oportuno, partes das amostras foram descongeladas à temperatura ambiente para que se procedesse a pré-secagem em estufa com ventilação forçada e temperatura controlada $\left(60^{\circ} \mathrm{C}\right.$ por 72 horas). Em seguida, o material foi moído em moinho de facas (tipo Willey) com peneiras de malha de $1 \mathrm{~mm}$. Na sequência, as amostras processadas foram submetidas a análises dos teores de matéria seca (MS), nitrogênio total $(\mathrm{NT})$, proteína bruta $(\mathrm{PB})$, lignina, extrato etéreo (EE), conforme procedimentos descritos por Silva e Queiroz (2002). O teor de nitrogênio insolúvel em detergente ácido (NIDA) foi determinado de acordo com os procedimentos descritos por Licitra, 
Hernandez e Van Soest (1996), sendo expressos como porcentagem do nitrogênio total. As análises para determinação dos teores de fibra em detergente neutro (FDN) e fibra em detergente ácido (FDA) (VAN SOEST, 1967) foram feitas em autoclave, conforme relatado por Pell e Schofield (1993).

Tabela 1. Composição bromatólogica do capim-elefante emurchecido e do capim-elefante não emurchecido aditivado com torta de mamona antes da ensilagem e da torta de mamona.

\begin{tabular}{|c|c|c|c|c|c|c|}
\hline \multirow[t]{2}{*}{ Item } & \multirow{2}{*}{$\begin{array}{l}\text { Capim-elefante } \\
\text { emurchecido }\end{array}$} & \multicolumn{4}{|c|}{$\begin{array}{l}\text { Capim-elefante não emurchecido contendo } \\
\text { torta de mamona }(\% \mathrm{MN})\end{array}$} & \multirow{2}{*}{$\begin{array}{l}\text { Torta de } \\
\text { mamona }\end{array}$} \\
\hline & & 0 & 6 & 12 & 18 & \\
\hline Matéria seca & 27,9 & 22,2 & 25,6 & 30,1 & 32,0 & 91,3 \\
\hline Extrato etéreo $^{1}$ & 2,2 & 2,5 & 2,0 & 2,3 & 2,7 & 2,2 \\
\hline Proteína bruta ${ }^{1}$ & 5,7 & 5,3 & 12,0 & 15,8 & 19,5 & 31,7 \\
\hline $\mathrm{NIDA}^{2}$ & 22,2 & 20,7 & 13,8 & 12,3 & 13,3 & 7,4 \\
\hline Nutrientes digestíveis totais ${ }^{1}$ & 48,1 & 51,5 & 46,9 & 43,8 & 41,9 & 60,3 \\
\hline DISMS $^{1}$ & 40,5 & 48,9 & 49,2 & 48,8 & 46,5 & 66,1 \\
\hline Fibra em detergente neutro ${ }^{1}$ & 78,0 & 75,1 & 66,2 & 69,1 & 65,7 & 42,8 \\
\hline FDNcp $^{1}$ & 76,6 & 73,9 & 62,5 & 60,6 & 59,6 & 39,9 \\
\hline Fibra em detergente ácido ${ }^{1}$ & 70,3 & 57,7 & 55,6 & 50,4 & 55,6 & 40,2 \\
\hline Hemicelulose $^{1}$ & 7,7 & 17,4 & 10,6 & 18,7 & 10,1 & 2,6 \\
\hline Celulose $^{1}$ & 59,0 & 47,7 & 42,8 & 33,3 & 35,4 & 27,8 \\
\hline Lignina $^{1}$ & 10,0 & 9,1 & 12,9 & 14,4 & 16,5 & 8,2 \\
\hline Carboidratos totais ${ }^{1}$ & 78,0 & 75,1 & 66,2 & 69,1 & 65,7 & 57,9 \\
\hline Carboidratos não fibrosos ${ }^{1}$ & 7,6 & 11,1 & 14,1 & 11,5 & 7,7 & 18,0 \\
\hline Matéria mineral $^{1}$ & 7,8 & 7,2 & 7,5 & 9,8 & 10,5 & 8,2 \\
\hline $\mathrm{pH}$ & 5,7 & 5,6 & 5,7 & 5,8 & 5,8 & $* * * *$ \\
\hline
\end{tabular}

NIDA = Nitrogênio insolúveis em detergente neutro; DISMS = Digestibilidade in situ da matéria seca; FDN = Fibra em detergente neutro corrigido para cinza e proteína; ${ }^{1}$ percentagem da matéria seca; ${ }^{2}$ percentagem do nitrogênio total.

Fonte: Laboratório de Forragicultura e Pastagem da Universidade Estadual do Sudoeste da Bahia.

O teor de fibra em detergente neutro corrigido para cinza e proteína (FDNcp) foi realizado segundo recomendações de Mertens (2002). Os carboidratos totais (CT) foram estimados segundo Sniffen et al. (1992), como: $\mathrm{CT}=100-(\% \mathrm{~PB}+\% \mathrm{EE}+\%$ cinza $)$. Os teores de carboidratos não-fibroso (CNF) foram calculados com adaptação do que foi proposto por Hall (2003), utilizando o FDNcp sendo: $\mathrm{CNF}=$ $(100-\%$ FDNcp $-\% \mathrm{~PB}-\% \mathrm{EE}-\%$ cinza $)$.

A estimação dos teores dos nutrientes digestíveis totais (NDT), conforme descrito por Weiss, Conrad e Pierre (1992), com modificações sugeridas pelo NRC (2001), representadas pelas equações a seguir:

$$
\mathrm{NDT}=\mathrm{CNFD}+\mathrm{PBD}+(\mathrm{AGD} \times 2,25)+\mathrm{FDND}-7
$$

Em que: $\mathrm{CNFD}=0,98\left\{100-\left[(\mathrm{FDN}-\mathrm{PIDN})^{*}\right.\right.$ $+\mathrm{PB}+\mathrm{EE}+$ Cinza $]\} \times$ FAP;

$$
\begin{aligned}
& \mathrm{PBD}=\mathrm{PB}[-1,2 \times(\mathrm{PIDA} / \mathrm{PB})] \\
& \mathrm{AGD}=\mathrm{AG}=\mathrm{EE}-1 . \mathrm{Se} \mathrm{EE}<1, \mathrm{AG}=0 ; \\
& \mathrm{FDND}=0,75 \times[(\mathrm{FDN}-\mathrm{PIDN}) *-\mathrm{Lig}] \times\{1-
\end{aligned}
$$
$[\mathrm{Lig} /(\mathrm{FDN}-\mathrm{PIDN}) *]$ 0,667\}

* Se a FDN for determinado adicionandose sulfito de sódio, não subtrair o PIDN; em que: CNFD = carboidratos não-fibrosos verdadeiramente digestíveis; $\mathrm{PBD}=$ proteína bruta verdadeiramente digestível; AGD = ácidos graxos verdadeiramente digestíveis; FDND = FDN verdadeiramente digestível; PIDN = proteína insolúvel em detergente 
neutro; FAP = fator de ajuste de processamento, neste caso, igual a 1; PIDA = proteína insolúvel em detergente ácido e Lig = lignina.

A digestibilidade in situ da matéria seca (DISMS) foi avaliada pelo método de incubação in situ, por um período de 48 horas, utilizando-se um novilho mestiço Holandês $\times$ Gir, com $280 \mathrm{~kg}$ de peso corporal, castrado, devidamente identificado e canulado no rúmen.

As amostras utilizadas na incubação ruminal foram moídas em peneira com crivos de $1 \mathrm{~mm}$ e acondicionadas em sacos de tecido-não-tecido, com dimensão de $5 \times 5 \mathrm{~cm}$, em quantidade de aproximadamente $0,5 \mathrm{~g}$ de $\mathrm{MS} / \mathrm{saco}$, buscando-se manter relação próxima de $20 \mathrm{mg}$ de $\mathrm{MS} / \mathrm{cm}^{2}$ de área superficial do saco (NOCEK, 1988). Após 48 horas de incubação ruminal, todos os sacos foram lavados manualmente em água corrente, até o momento em que a água ficasse transparente, em seguida, foram secos em estufa de ventilação forçada a $60^{\circ} \mathrm{C}$, por 72 horas, e imediatamente pesados para determinação da digestibilidade in situ da matéria seca.

Para as frações que compõe os carboidratos, estimou-se da seguinte forma: as frações $A+B 1$ correspondem aos carboidratos não-fibrosos (CNF). Já para a fração C, foi estimada pela FDN indigestível, após 240 horas de incubação in situ (CASALI et al., 2008), logo, a fração B2, que corresponde à fração disponível da fibra, foi obtida pela diferença entre a FDNcp e a fração C.

As frações proteicas foram obtidas conforme método descrito por AOAC (1995). A fração A, que corresponde ao nitrogênio não proteico (NNP), foi determinada a partir da adição de água destilada (5 mL), em aproximadamente $0,5 \mathrm{~g}$ de amostra, deixando a solução em repouso por 30 minutos. Após decorrer o tempo, o material foi centrifugado a $10.000 \mathrm{rpm}$, por 20 minutos. Em seguida, adicionouse solução de ácido tricloroacético - TCA ( $5 \mathrm{~mL})$ a $20 \%$ e deixou-se descansar por 3 horas. Decorrido o período, o material foi novamente centrifugado a $10.000 \mathrm{rpm}$, por 20 minutos, coletando-se $2 \mathrm{~mL}$ do sobrenadante e transferido para um tubo de determinação de nitrogênio. Procedeu-se então a estimação do teor de nitrogênio no líquido pelo método MicroKjeldahl, para quantificação dos compostos nitrogenados não proteicos. A fração B3 da proteína foi obtida pela diferença entre NIDN e NIDA, e para fração C foi considerado o NIDA, ao passo que a proteína verdadeira solúvel em detergente neutro (frações B1+B2) foi obtida pela diferença entre as frações $\mathrm{A}, \mathrm{B} 3$ e $\mathrm{C}$ como se segue: $\mathrm{B} 1+\mathrm{B} 2=100-[\mathrm{NNP}+(\mathrm{NIDN}-\mathrm{NIDA})+\mathrm{NIDA}]$.

De maneira resumida, as frações proteicas foram estimadas como se segue: Fração A = NNP; Frações $(\mathrm{B} 1+\mathrm{B} 2)=100-[\mathrm{NNP}+(\mathrm{NIDN}-\mathrm{NIDA})+\mathrm{NIDA}] ;$ Fração B3 $=$ NIDN - NIDA; $C=$ NIDA.

$\mathrm{O}$ efeito das doses da torta de mamona foi avaliado por meio das análises de variância e regressão, adotando-se o nível de $1 \%$ de probabilidade. Já a comparação entre a silagem de capim-elefante emurchecido (Testemunha) com as silagens de capim-elefante contendo ou não torta de mamona, $(0 \% ; 6 \% ; 12 \%$ e $18 \%$ na matéria natural), foi realizada pelo teste de Dunnett, adotandose o nível de 5\% de probabilidade, utilizou-se o programa Sistema de Análises Estatísticas e Genéticas - SAEG (RIBEIRO JÚNIOR, 2001).

\section{Resultados e Discussão}

A silagem não emurchecida ou contendo $6 \%$ de torta de mamona apresentaram valores de $\mathrm{pH}$ similares $(\mathrm{P}>0,05)$ ao da silagem emurchecida, sendo, respectivamente, de 3,6; 3,8 e 3,7\%. As silagens contendo 12 ou $18 \%$ de torta de mamona, entretanto, diferiram $(\mathrm{P}<0,05)$ da silagem emurchecida, sendo verificado respectivos valores de $\mathrm{pH}$ de 4,0 e 4,8 (Tabela 2). A equação de regressão para o $\mathrm{pH}$ apresentou comportamento linear crescente (Tabela 2), assim, para cada unidade percentual de torta de mamona adicionada à ensilagem, ocorreu um acréscimo de 0,06 unidade no $\mathrm{pH}$. Porém, o aumento de $\mathrm{pH}$ observado não refletiu em silagem de baixa qualidade, uma vez que o coproduto foi eficiente em reduzir as perdas. 
Tabela 2. Teor médio de $\mathrm{pH}$ e teores de nitrogênio amoniacal $\left(\mathrm{N}^{-\mathrm{NH}_{3}}\right)$, perdas por gases $(\mathrm{PG})$, perdas por efluente (PE), perdas totais (PT), índice de recuperação da matéria seca (IRMS) e coeficiente de variação (CV), da silagem de capim-elefante emurchecido e das silagens de capim-elefante não emurchecido aditivado com torta de mamona, equação de regressão (Eq.) e coeficiente de determinação $\left(\mathrm{r}^{2} / \mathrm{R}^{2}\right)$, em função das doses de torta de mamona no capimelefante não emurchecido.

\begin{tabular}{|c|c|c|c|c|c|c|c|c|}
\hline \multirow{2}{*}{ Item } & \multirow{2}{*}{$\begin{array}{l}\text { Capim-elefante } \\
\text { emurchecido }\end{array}$} & \multicolumn{4}{|c|}{ Torta de mamona (\% MN) } & \multirow{2}{*}{ CV (\%) } & \multirow{2}{*}{$\begin{array}{l}\text { Equação de } \\
\text { regressão }\end{array}$} & \multirow{2}{*}{$r^{2} / R^{2}$} \\
\hline & & 0 & 6 & 12 & 18 & & & \\
\hline $\mathrm{pH}$ & 3,7 & 3,6 & 3,8 & $4,0^{*}$ & $4,8^{*}$ & 1,6 & Eq. 1 & 86,9 \\
\hline $\mathrm{N}-\mathrm{NH}_{3}{ }^{1}$ & 10,4 & $12,8^{*}$ & $4,9^{*}$ & $3,3^{*}$ & $2,4^{*}$ & 7,0 & Eq. 2 & 78,1 \\
\hline $\mathrm{PG}^{2}$ & 10,1 & $0,5^{*}$ & $0,3 *$ & $4,6^{*}$ & $2,0^{*}$ & 3,5 & Eq. 3 & NS \\
\hline $\mathrm{PE}^{3}$ & 30,4 & $72,9^{*}$ & $46,8^{*}$ & 24,2 & $12,9^{*}$ & 17,4 & Eq. 4 & 92,2 \\
\hline $\mathrm{PT}^{2}$ & 12,9 & $7,5^{*}$ & $4,5^{*}$ & $6,6^{*}$ & $3,1^{*}$ & 11,6 & Eq. 5 & NS \\
\hline IRMS $^{2}$ & 87,0 & $92,2 *$ & $95,3 *$ & $92,6^{*}$ & $97,4^{*}$ & 1,2 & Eq. 6 & NS \\
\hline
\end{tabular}

* Médias seguidas por asterisco diferem da testemunha a 5\% de probabilidade pelo teste de Dunnett; ${ }^{1}$ Porcentagem do nitrogênio total; ${ }^{2}$ Porcentagem da matéria seca; ${ }^{3} \mathrm{~kg}$ por tonelada de matéria verde (kg/t MV). Equações: $1: \hat{\mathrm{Y}}=3,47050+0,0659167^{* *} \mathrm{x}$ $\mathrm{TM} ; 2: \hat{\mathrm{Y}}=10,7540-0,544334^{* *} \mathrm{x}$ TM; $3: \hat{\mathrm{Y}}=1,86677 ; 4: \hat{\mathrm{Y}}=72,5546-3,72028^{* *} \mathrm{x} \mathrm{TM} ; 5: \hat{\mathrm{Y}}=5,68090 ; 6: \hat{\mathrm{Y}}=94,3012 . * *$ Significativo a $1 \%$ de probabilidade, pelo teste F; NS: não significativo.

Fonte: Elaboração dos autores.

Os valores de $\mathrm{pH}$ observados para as silagens emurchecida, não emurchecida, contendo 6 ou $12 \%$ de torta de mamona, encontraram-se dentro de uma margem adequada à conservação, sendo que McDonald, Herderson eHerson(1991) preconizaram que silagens de boa qualidade apresentam valores de $\mathrm{pH}$ entre 3,6 a 4,2. Entretanto, a silagem contendo $18 \%$ de torta de mamona apresentou valor de $\mathrm{pH}$ superior ao índice citado. Segundo Jobim et al. (2007), silagens de materiais com baixo teor de umidade, invariavelmente, apresentam valores de $\mathrm{pH}$ elevados (acima de 4,2).

$\mathrm{Na}$ avaliação do nitrogênio amoniacal (N$\mathrm{NH}_{3}$ ), verificou-se que a silagem (Tabela 2) não emurchecida $(0 \%$ de torta de mamona) e as contendo 6,12 ou $18 \%$ de torta de mamona apresentaram valores, respectivamente, de 12,8; 4,$9 ; 3,3$ e 2,4\% de N-total, que diferiram $(\mathrm{P}<0,05)$ da silagem emurchecida $(10,4 \%)$. Ao comparar o teor de $\mathrm{N}_{-} \mathrm{NH}_{3}$ da silagem de capim-elefante emurchecido com o não emurchecido, observa-se que o emurchecimento foi eficiente em reduzir o teor de $\mathrm{N}-\mathrm{NH}_{3}$, uma vez que, no período de exposição ao sol são desencadeados processos enzimáticos que degradam proteínas, com consequente diminuição do teor desse nutriente, no momento da ensilagem, o que contribuiu para diminuição da produção de $\mathrm{N}^{-\mathrm{NH}_{3}}$ pelas bactérias durante a fermentação. Verificou-se efeito linear decrescente (Tabela 2), sendo observada, para cada unidade percentual de torta de mamona adicionada, uma redução de 0,54 unidades de $\mathrm{N}-\mathrm{NH}_{3}$.

$\mathrm{O}$ maior teor de $\mathrm{N}_{-} \mathrm{NH}_{3}$ observado para a silagem não emurchecida está relacionado ao maior teor de umidade na massa ensilada (Tabela 1) que se remete a uma maior atividade de água, a qual pode proporcionar um maior desenvolvimento de bactérias indesejáveis, como as do gênero Clostridium que, além de consumir o ácido lático essencial para o abaixamento do $\mathrm{pH}$, degrada a proteína, reduzido-as em $\mathrm{N}-\mathrm{NH}_{3}$, diminuindo a qualidade da silagem.

Nos resultados verificados para as perdas por gases (Tabela 2), as silagens não emurchecidas e contendo 6,12 ou $18 \%$ de torta de mamona apresentaram menores perdas, respectivamente, de 0,$5 ; 0,3 ; 4,6$ e $2,0 \%$ do que a silagem emurchecida $(10,1 \%)$. As menores perdas por gases verificados para a silagem não emurchecida ou contendo $6 \%$ de torta de mamona podem ser devido às maiores 
perdas por efluente (Tabela 2) que, nesta situação, ocorreu percolação dos carboidratos solúveis, ácidos orgânicos e outros componentes do conteúdo celular, ocasionando uma menor fermentação. Já para silagens contendo 12 ou $18 \%$ de torta de mamona que, também, apresentaram menores perdas por gases, a maior proporção de torta de mamona, no momento da ensilagem, ocasionou uma redução no teor de carboidratos não fibrosos (Tabela 1) e isso pode ter proporcionado uma diminuição na produção de gases, oriundos da fermentação microbiana. Como o processo de emurchecimento não foi eficiente em elevar o teor de matéria seca da forragem (Tabela 1) ocorreu uma maior fermentação dos carboidratos solúveis remanescentes, elevando as perdas por gases (Tabela 2).

As perdas por efluente da silagem contendo $12 \%$ de torta de mamona $(24,2 \mathrm{~kg} / \mathrm{t}$ de matéria verde $(\mathrm{MV}))$ foi similar $(\mathrm{P}>0,05)$ ao da silagem emurchecida $(30,4 \mathrm{~kg} / \mathrm{t} \mathrm{MV})$. As perdas por efluentes nas silagens não emurchecidas e contendo 6 ou $18 \%$ de torta de mamona diferiram $(\mathrm{P}<0,05)$ da silagem emurchecida, apresentando, respectivamente, de 72,9; 46,8 e 12,9 kg/t MV. A maior perda verificada para a silagem não emurchecida já era esperada, uma vez que a forragem ensilada apresentava baixo teor de matéria seca (22,2\%) (Tabela 1). Verificou-se efeito linear decrescente $(\mathrm{P}<0,01)$ para as perdas por efluente, em função das doses de torta de mamona (Tabela 2). Contudo, para cada unidade percentual de torta adicionada à forragem, ocorreu redução de 3,72 unidades percentuais de perdas por efluente na ensilagem.

Verificou-se que as perdas totais para as silagens, não emurchecida, contendo 6,12 ou $18 \%$ de torta de mamona, apresentaram médias de 7,5; 4,5; 6,6 e 3,1\%, respectivamente (Tabela 2). As perdas totais observadas diferiram $(\mathrm{P}<0,05)$ da silagem emurchecida (12,9\%), no entanto, o menor teor de
$\mathrm{N}-\mathrm{NH}_{3}$ e as menores perdas por gases e efluente contribuíram para obtenção de menores perdas totais, verificado para a silagem contendo $18 \%$ de torta de mamona. Com relação as diferentes doses de torta de mamona $(0,6,12$ e $18 \%)$ adicionadas no ensilado, verificou-se que, independente da dose utilizada, as perdas totais apresentaram valor médio de 5,68\% (Tabela 2). As perdas totais observadas se encontram abaixo de $10 \%$, conferindo as silagens uma maior manutenção do valor nutritivo.

Com relação ao índice de recuperação da matéria seca (IRMS), pode-se destacar que as silagens, não emurchecida, contendo 6,12 ou $18 \%$ de torta de mamona, apresentaram valores, respectivamente, de 92,$2 ; 95,3 ; 92,6$ e 97,4\%, diferindo $(\mathrm{P}<0,05)$ da silagem emurchecida $(87,0 \%)$. Para a silagem emurchecida, os menores IRMS podem ser devido as maiores perdas totais verificadas para estas silagens. Diante dos fatos apresentados, a utilização da torta de mamona na ensilagem de capim-elefante é mais eficiente em reduzir as perdas de silagem do que a técnica do emurchecimento.

Para o teor de matéria seca, foi verificado que a silagem emurchecida equiparou-se $(\mathrm{P}>0,05)$ à silagem contendo $6 \%$ de torta de mamona, apresentando valores, respectivamente, de 25,3 e $26,1 \%$ (Tabela 3 ). No entanto, a silagem não emurchecida e as contendo 12 ou $18 \%$ de torta de mamona apresentaram os respectivos teores, 22,$3 ; 29,0$ e $31,9 \%$ de $\mathrm{MS}$, que diferiram $(\mathrm{P}<0,05)$ da silagem emurchecida (Tabela 3). Diante dos resultados apresentados, não há diferença entre fazer o emurchecimento ou adicionar $6 \%$ de torta à ensilagem, porém, a última opção pode incrementar a composição da silagem, sobretudo, no teor de proteína bruta. A inclusão de doses crescentes de torta de mamona (Tabela 3) proporcionou aumento linear $(\mathrm{P}<0,01)$ no teor de matéria seca das silagens. 
Tabela 3. Teores médios da matéria seca (MS), matéria mineral (MM), extrato etéreo (EE), proteína bruta (PB), nitrogênio insolúvel em detergente ácido (NIDA), nutrientes digestíveis totais (NDT), digestibilidade in situ da matéria seca (DISMS) e coeficiente de variação (CV), da silagem de capim-elefante emurchecido e das silagens de capimelefante não emurchecido aditivado com torta de mamona, equação de regressão (Eq.) e coeficiente de determinação $\left(\mathrm{r}^{2} / \mathrm{R}^{2}\right)$, em função das doses de torta de mamona no capim-elefante não emurchecido.

\begin{tabular}{lcccccccc}
\hline \multirow{2}{*}{ Item } & $\begin{array}{c}\text { Capim-elefante } \\
\text { emurchecido }\end{array}$ & \multicolumn{4}{c}{ Torta de mamona (\% MN) } & \multirow{2}{*}{$\mathrm{CV}(\%)$} & $\begin{array}{c}\text { Equação de } \\
\text { regressão }\end{array}$ & $\mathrm{r}^{2} / \mathrm{R}^{2}$ \\
\hline $\mathrm{MS}$ & 25,3 & $22,3^{*}$ & 26,1 & $29,0^{*}$ & $31,9^{*}$ & 1,6 & Eq. 1 & 98,5 \\
$\mathrm{MM}^{1}$ & 7,3 & 6,8 & 6,6 & $9,5^{*}$ & $10,7^{*}$ & 13,2 & Eq. 2 & 64,5 \\
$\mathrm{EE}^{1}$ & 4,3 & $3,4^{*}$ & 4,2 & 4,4 & $3,3^{*}$ & 10,3 & Eq. 3 & 73,7 \\
$\mathrm{~PB}^{1}$ & 4,9 & $4,2^{*}$ & $10,3^{*}$ & $13,8^{*}$ & $17,6^{*}$ & 3,0 & Eq. 4 & 97,8 \\
$\mathrm{NIDA}^{2}$ & 15,1 & 5,4 & $12,0^{*}$ & $11,4 *$ & $9,4^{*}$ & 7,5 & Eq. 5 & 83,3 \\
$\mathrm{NDT}^{1}$ & 51,1 & 51,2 & $46,7^{*}$ & $44,9^{*}$ & $41,7^{*}$ & 4,4 & Eq. 6 & 77,4 \\
DISMS $^{1}$ & 41,6 & 45,0 & $46,9^{*}$ & $47,0^{*}$ & $46,6^{*}$ & 4,1 & Eq. 7 & $\mathrm{NS}$ \\
\hline
\end{tabular}

* Médias seguidas por asterisco diferem da testemunha a $5 \%$ de probabilidade pelo teste de Dunnett; ${ }^{1}$ percentagem da matéria seca; ${ }^{2}$ percentagem do nitrogênio total. Equações: $1: \hat{Y}=22,5419+0,529399^{* *}$ x TM; $2: \hat{Y}=6,19154+0,243971^{* *}$ x TM; $3: \hat{Y}=$ $3,38591+0,234043^{* *} \times \mathrm{TM}-0,0131604^{* *} \times \mathrm{TM}^{2} ; 4: \hat{\mathrm{Y}}=4,89595+0,731909^{* *}$ x TM; $5: \hat{\mathrm{Y}}=14,8976-0,313995^{* *} \times \mathrm{TM} ; 6: \hat{\mathrm{Y}}=$ $50,6338-0,503726^{* *} \times \mathrm{TM} ; 7: \hat{\mathrm{Y}}=46,36313 .{ }^{*} *$ Significativo a $1 \%$ de probabilidade, pelo teste F. NS: não significativo.

Fonte: Elaboração dos autores.

Diante dos dados apresentados, pode-se afirmar que a inclusão da torta de mamona, principalmente, nas doses 12 e $18 \%$, foi mais eficiente em diminuir a umidade do capim-elefante do que a técnica do emurchecimento. Essa constatação foi realizada mediante observação dos teores de MS, que se aproximaram dos níveis mais adequados para o processo de ensilagem.

Para o extrato etéreo, verificou-se que as silagens aditivadas com 6 e 12\% de torta de mamona não diferiram $(\mathrm{P}>0,05)$ da silagem emurchecida, que apresentaram médias, respectivamente, de 4,2; 4,4 e $4,3 \%$. De maneira oposta, observou-se que as silagens não emurchecidas e contendo $18 \%$ de torta de mamona apresentaram menor teor de extrato etéreo (3,4 e 3,3\%, respectivamente), diferindo $(\mathrm{P}<0,05)$ da silagem emurchecida (Tabela 3). Houve efeito quadrático $(\mathrm{P}<0,01)$ das doses de torta de mamona sobre o teor de extrato etéreo. Desta maneira, verificou-se um valor máximo de extrato etéreo de $4,4 \%$ para a dose de $8,9 \%$ de torta de mamona adicionada ao ensilado (Tabela 3 ).

O teor de proteína bruta, verificado para a silagem emurchecida $(4,9 \%)$, diferiu $(\mathrm{P}<0,05)$ das silagens contendo $0,6,12$ ou $18 \%$ de torta de mamona, sendo observados teores, respectivamente, de 4,2; 10,3; 13,8 e 17,6\% (Tabela 3). O menor teor de proteína bruta verificado para a silagem não emurchecida pode estar relacionado à maior produção de $\mathrm{N}^{-\mathrm{NH}_{3}}$, apresentado por esse tratamento (Tabela 2). Já os maiores teores de proteína bruta, verificado para as silagens contendo 6,12 ou $18 \%$ de torta da mamona, se devem ao fato do coproduto utilizado ser um concentrado proteico $(31,7 \%$ de proteína bruta) (Tabela 1). A adição da torta de mamona ao capimelefante, no momento da ensilagem, aumentou $(\mathrm{P}<0,01)$ de forma linear os teores de proteína bruta da silagem, sendo que, para cada unidade percentual de torta, adicionada à forragem, proporcionou acréscimo de 0,73 unidades percentuais de proteína bruta na silagem (Tabela 3 ).

Para o nitrogênio insolúvel em detergente ácido (NIDA), verificou-se que a silagem não emurchecida $(15,4 \%)$ apresentou teores semelhantes $(\mathrm{P}>0,05)$ ao da silagem emurchercida $(15,1 \%)$, porém as silagens contendo torta de mamona $(6,12$ ou $18 \%)$ diferiram $(\mathrm{P}<0,05)$ da silagem emurchecida, apresentando teores, respectivamente, de 12,0; 11,4 
e 9,4\% (Tabela 3). Maiores benefícios foram obtidos ao utilizar o coproduto em detrimento à técnica do emurchecimento, uma vez que os teores de NIDA foram reduzidos com a utilização da torta de mamona, enquanto que o emurchecimento manteve elevado o teor desse nutriente na silagem. Assim, para cada unidade percentual de torta adicionada à forragem, houve uma redução de 0,31 unidades no teor de NIDA. Estes resultados podem ser devido ao fato do coproduto apresentar menor teor de NIDA $(7,4 \%)$ em comparação com a forragem capimelefante (20,7\%) (Tabela 3).

Analisando as estimativas dos nutrientes digestíveis totais (NDT), pode-se verificar que a silagem não emurchecida $(51,2 \%)$ não diferiu $(\mathrm{P}>0,05)$ da silagem emurchecida $(51,1 \%)$, entretanto, as silagens contendo 6,12 ou $18 \%$ de torta de mamona diferiram $(\mathrm{P}<0,05)$ da silagem emurchecida, apresentando valores, respectivamente, de 46,7; 44,9 e 41,7\% (Tabela 3). A adição da torta de mamona ao capim-elefante, no momento da ensilagem, reduziu $(\mathrm{P}<0,01)$ de forma linear os teores de NDT da silagem, sendo que, para cada unidade percentual de torta, adicionada à forragem, proporcionou decréscimo de 0,50 unidades percentuais de proteína bruta na ensilagem (Tabela 3).

$\mathrm{Na}$ avaliação da digestibilidade in situ da matéria seca (DISMS), a silagem não emurchecida (45,0\%) não diferiu $(\mathrm{P}>0,05)$ da silagem emurchecida (41,6\%), entretanto, as silagens contendo 6,12 ou $18 \%$ de torta de mamona diferiram $(\mathrm{P}<0,05)$ da silagem emurchecida, apresentando valores, respectivamente, de 46,9; 47,0 e 46,6\% (Tabela 3). Entretanto, no que se referem às silagens contendo $0,6,12$ e $18 \%$ de torta de mamona, não foi verificado ajuste de regressão na DISMS entre as silagens, sendo observado valor médio de $46,6 \%$ (Tabela 3 ).

Os teores de fibra em detergente neutro (FDN) e FDNcp das silagens contendo 6, 12 e 18\% de torta de mamona diferiram $(\mathrm{P}<0,05)$ da silagem emurchecida, enquanto a silagem de capimelefante não emurchecida apresentou valores similares $(\mathrm{P}>0,05)$ ao da silagem emurchecida (Tabela 4). Ao considerar-se, apenas, os teores de inclusão de torta de mamona na forragem capimelefante, os teores de FDN e FDNcp apresentaram comportamento linear decrescente $(\mathrm{P}<0,01)$, estimando-se, respectivamente, reduções de 0,57 e 0,80 unidades percentuais por unidade de torta de mamona adicionada à forragem. Isso se deve, provavelmente, ao menor teor de FDN da torta de mamona (42,8\% da MS) em relação ao capimelefante $(75,1 \%)$ (Tabela 1$)$. A redução no teor de FDN das silagens, à medida que se adicionou a torta de mamona, representa ponto positivo para nutrição de ruminantes, uma vez que a concentração de FDN das dietas tem sido apontada como um dos principais reguladores do consumo por sua lenta degradação e reduzida taxa de passagem. Se a ingestão é reduzida pela limitação física, alimentos com alto teor de FDN, como os volumosos, poderão ter sua ingestão restringida, limitando a expressão do potencial genético do animal para produção (CARVALHO et al., 2006). 
Tabela 4. Teores médios da fibra em detergente neutro (FDN), fibra em detergente neutro corrigido (FDNcp), fibra em detergente ácido (FDA), hemicelulose, celulose, lignina, carboidratos totais (CT), carboidratos não fibrosos (CNF) e coeficiente de variação (CV), da silagem de capim-elefante emurchecido e das silagens de capim-elefante não emurchecido aditivado com torta de mamona, equação de regressão (Eq.) e coeficiente de determinação $\left(\mathrm{r}^{2} / \mathrm{R}^{2}\right)$, em função das doses de torta de mamona no capim-elefante não emurchecido.

\begin{tabular}{lcccccccc}
\hline \multirow{2}{*}{ Item } & $\begin{array}{c}\text { Capim-elefante } \\
\text { emurchecido }\end{array}$ & \multicolumn{4}{c}{ Torta de mamona (\% MN) } & \multirow{2}{*}{ CV (\%) } & $\begin{array}{c}\text { Equação de } \\
\text { regressão }\end{array}$ & $\mathrm{r}^{2} / \mathrm{R}^{2}$ \\
\hline FDN $^{1}$ & 80,0 & 79,2 & $73,2^{*}$ & $70,2^{*}$ & $68,8^{*}$ & 3,4 & Eq. 1 & 66,7 \\
FDNcp $^{1}$ & 78,8 & 77,5 & $69,9^{*}$ & $65,0^{*}$ & $63,0^{*}$ & 3,6 & Eq. 2 & 78,7 \\
FDA $^{1}$ & 67,8 & 66,8 & $63,3^{*}$ & $61,9^{*}$ & $55,4^{*}$ & 3,7 & Eq. 3 & 73,6 \\
Hemicelulose $^{1}$ & 12,4 & 15,0 & 9,9 & $7,8^{*}$ & 14,0 & 19,6 & Eq. 4 & 62,9 \\
Celulose $^{1}$ & 57,0 & 55,6 & $47,5^{*}$ & $41,7^{*}$ & $32,0^{*}$ & 3,2 & Eq. 5 & 96,6 \\
Lignina $^{1}$ & 10,0 & 10,3 & $14,2^{*}$ & $16,2^{*}$ & $20,8^{*}$ & 7,1 & Eq. 6 & 93,2 \\
CT $^{1}$ & 83,3 & 85,7 & $78,8^{*}$ & $72,3^{*}$ & $68,4^{*}$ & 1,7 & Eq. 7 & 95,7 \\
CNF $^{1}$ & 4,4 & $7,4^{*}$ & $7,9^{*}$ & $7,3^{*}$ & $8,1^{*}$ & 11,7 & Eq. 8 & NS \\
\hline
\end{tabular}

* Médias seguidas por asterisco diferem da testemunha a $5 \%$ de probabilidade pelo teste de Dunnett; ${ }^{1}$ percentagem da matéria seca. Equações: 1: $\hat{Y}=77,9892-0,570019^{* *}$ x TM; $2: \hat{Y}=76,1072-0,803930^{* *}$ x TM; 3: $\hat{Y}=67,1726-0,593107^{* *}$ x TM; $4: \hat{Y}$ $=15,2203-1,48713^{* *} \times \mathrm{TA}+0,0778827^{* *} \times \mathrm{TM}^{2} ; 5: \hat{\mathrm{Y}}=55,6532-1,27439^{* *} \times \mathrm{TM} ; 6: \hat{\mathrm{Y}}=10,3230+0,561287^{* *} \times \mathrm{TM} ; 7: \hat{\mathrm{Y}}=$ $85,0528-0,973036^{* *} \times \mathrm{TM} ; 8: \hat{\mathrm{Y}}=7,66770 .{ }^{* *}$ Significativo a $1 \%$ de probabilidade, pelo teste F; NS: Não significativo.

Fonte: Elaboração dos autores.

Houve diferença $(\mathrm{P}<0,05)$ no teor de fibra em detergente ácido (FDA) entre a silagem de capimelefante emurchecido $(67,8 \%)$ e as silagens contendo 6,12 e $18 \%$ de torta de mamona, respectivamente, de 63,$3 ; 61,9$ e 55,4\% (Tabela 4). A adição de doses crescentes de torta de mamona ao capim-elefante resultou em decréscimo linear $(\mathrm{P}<0,01)$ sobre o teor de FDA das silagens, provavelmente, devido ao menor teor de FDA na torta de mamona (Tabela 1).

Para o teor de lignina, apenas a silagem produzida com capim-elefante não emurchecido apresentou valor similar ao da silagem de capim emurchecido. As demais silagens (6, 12 e $18 \%$ de adição de torta de mamona) foram superiores ao tratamento emurchecido. Observou-se aumento linear no teor de lignina em função das doses de torta de mamona (Tabela 4), estimando-se acréscimo de 0,56 unidades percentuais de lignina por unidade de torta de mamona.

Os teores de carboidratos totais variaram em função do emurchecimento e das doses de torta de mamona (Tabela 4). As silagens de capimelefante, contendo 6,12 e $18 \%$ de torta de mamona, apresentaram teor de carboidratos totais inferiores $(\mathrm{P}<0,05)$ ao da silagem de capim-elefante emurchecido. Por outro lado, a silagem de capimelefante não emurchecido apresentou valores de carboidratos totais similares $(\mathrm{P}>0,05)$ ao da silagem de capim emurchecido. Doses crescentes de torta de mamona adicionadas a forragem no momento da ensilagem provocaram decréscimo nos teores de carboidratos totais, sendo observado uma diminuição de 0,97 unidades percentuais de carboidratos totais para cada unidade de torta de mamona adicionada.

Os teores de carboidratos são fortemente influenciados pelos teores de proteína bruta e extrato etéreo, haja vista a utilização dessas variáveis para determinação dos carboidratos totais, conforme modelo proposto por Sniffen et al. (1992). Portanto, como a torta de mamona apresenta valores consideráveis destes nutrientes (Tabela 1), provavelmente, isso favoreceu a diminuição no teor dos carboidratos totais ao utilizar doses crescentes de torta de mamona no ensilado.

Ao considerar apenas os níveis de inclusão da 
torta de mamona à ensilagem, pode-se observar que os teores de CNF foram semelhantes $(\mathrm{P}>0,01)$, e apresentaram média de 7,7\%. Contudo, verificase que os teores de CNF do material, no momento da ensilagem, contendo $0,6,12$ ou $18 \%$ foram, respectivamente, de 11,$1 ; 16,4 ; 6,5$ e 7,7\% (Tabela 1). Ao observar os respectivos teores encontrados na silagem (Tabela 4), percebe-se que para as silagens aditivadas com 0 e $6 \%$ de torta de mamona não houve manutenção nos teores de CNF.

Por outro lado, ao comparar as concentrações de CNF do material, no momento da ensilagem, contendo 12 e 18\% de torta de mamona (Tabela 1), com a silagem das respectivas doses (Tabela 4), observa-se que não houve utilização desse nutriente no processo de fermentação. Possivelmente a redução da umidade pela adição da torta de mamona nas doses supracitadas (Tabela 3 ) pode ter reduzido a atividade água e esta, por sua vez, não favoreceu a proliferação de microrganismos que utilizam esse nutriente.

Para as frações dos carboidratos com elevada taxa de degradação ruminal $(\mathrm{A}+\mathrm{B} 1)$, foram verificados que as silagens não emurchecidas $(0 \%$ de torta de mamona), contendo 6,12 ou $18 \%$ de torta de mamona, apresentaram valores, respectivamente, de 7,$4 ; 8,4 ; 7,3$ e $8,1 \%$ que diferiam $(\mathrm{P}<0,05)$ da silagem emurchecida $(4,4 \%)$ (Tabela 5). Contudo, na silagem emurchecida não houve manutenção do teor da fração $\mathrm{A}+\mathrm{B} 1$ (carboidratos não-fibrosos), quando comparada com o material no momento da ensilagem (Tabela 1), podendo ser atribuídas as perdas por gases que ocorreram (Tabela 3), pois esta fração é o principal substrato utilizado pelas bactérias ácido láticas. Entretanto, para as silagens contendo 0 e $6 \%$ de torta de mamona, também, observou-se redução no teor das frações $\mathrm{A}+\mathrm{B} 1$ na abertura do silo em relação à ensilagem. Fato este que, possivelmente, ocorreu devido ao menor teor de MS apresentado pelas silagens supracitadas no momento da ensilagem. Por outro lado, como a adição de 12 e $18 \%$ de torta de mamona no capimelefante foi eficiente em aumentar o teor de MS do material ensilado e incrementos nas frações $\mathrm{A}+\mathrm{B} 1$ foram verificados para esses tratamentos (Tabela 5).

$\mathrm{Na}$ fração $\mathrm{A}+\mathrm{B} 1$ (Tabela 5), verificou-se que para as silagens contendo $0,6,12$ ou $18 \%$ de torta de mamona, não houve diferença $(\mathrm{P}>0,01)$, apresentando valor médio de 7,8\%. Pode-se constatar que os teores médios dessa fração dos carboidratos foram menores que $10 \%$, sendo assim, a inclusão da torta de mamona não promoveu incremento, apesar do teor de CNF desse coproduto ser de 18\% (Tabela 1). Esse fato pode ser atribuído ao consumo desta fração pelas bactérias fermentadoras de carboidratos não fibrosos, para aumento da população com consequente produção de ácidos orgânicos, que promovem a redução do $\mathrm{pH}$, ou também pode ser atribuída à maior perda por efluente, na qual, em meio à solução, são carreados (açúcares solúveis e ácidos orgânicos) para o fundo do silo, promovendo redução da fração $\mathrm{A}+\mathrm{B} 1$.

Contudo, vale ressaltar que, em dietas para ruminantes contendo fontes proteicas de rápida e média degradação no rúmen, é essencial a utilização de outra fonte de alimento de elevado teor de carboidratos não fibrosos, para que ocorra melhor sincronização entre a liberação de energia e nitrogênio, uma vez que as silagens estudadas apresentaram baixos teores da fração $\mathrm{A}+\mathrm{B} 1$.

Para os carboidratos fibrosos, potencialmente digestíveis (Fração B2), verificou-se que as silagens não emurchecidas, contendo 6,12 ou $18 \%$ de torta de mamona, não diferiram da silagem emurchecida, apresentando valor médio de 55,3\% (Tabela 5). Desta maneira, pode-se afirmar que, tanto o emurchecimento quanto a adição de torta de mamona ensilada não promoveram maior disponibilidade da fração B2. Isso, provavelmente, ocorreu devido aos baixos teores de hemicelulose e celulose, verificados na torta de mamona (Tabela 1). 
Tabela 5. Teores médios de carboidratos não fibrosos $(\mathrm{A}+\mathrm{B} 1)$, componentes da parede celular disponíveis, que correspondem à fração potencialmente degradável (B2), fração indigestível da parede celular (C), bem como as frações proteicas correspondentes ao nitrogênio não proteico (A), fração de rápida e de intermediária degradação $(\mathrm{B} 1+\mathrm{B} 2)$, fração de lenta degradação (B3), fração não digestível (C) e coeficiente de variação (CV) da silagem de capimelefante emurchecido e das silagens de capim-elefante não emurchecido aditivado com torta de mamona, equação de regressão (Eq.) e coeficiente de determinação $\left(\mathrm{r}^{2} / \mathrm{R}^{2}\right)$, em função das doses de torta de mamona no capim-elefante não emurchecido.

\begin{tabular}{|c|c|c|c|c|c|c|c|c|}
\hline \multirow{2}{*}{ Item } & \multirow{2}{*}{$\begin{array}{c}\text { Capim-elefante } \\
\text { emurchecido }\end{array}$} & \multicolumn{4}{|c|}{ Torta de mamona (\% MN) } & \multirow{2}{*}{$\mathrm{CV}(\%)$} & \multirow{2}{*}{$\begin{array}{l}\text { Equação de } \\
\text { regressão }\end{array}$} & \multirow{2}{*}{$r^{2} / R^{2}$} \\
\hline & & 0 & 6 & 12 & 18 & & & \\
\hline \multicolumn{9}{|c|}{ Frações dos carboidratos $(\%$ CT) } \\
\hline $\mathrm{A}+\mathrm{B} 1$ & 4,4 & $7,4^{*}$ & $8,4^{*}$ & $7,3 *$ & $8,1^{*}$ & 13,3 & Eq. 1 & NS \\
\hline B2 & 53,4 & 55,6 & 56,6 & 59,2 & 51,6 & 5,0 & Eq. 2 & NS \\
\hline $\mathrm{C}$ & 42,2 & 37,0 & $35,0^{*}$ & $33,5^{*}$ & 40,3 & 7,6 & Eq. 3 & NS \\
\hline \multicolumn{9}{|c|}{ Frações de proteicas (\% NT) } \\
\hline A & 50,2 & 49,7 & 48,2 & $44,2 *$ & $36,8 *$ & 5,1 & Eq. 4 & 82,0 \\
\hline $\mathrm{B} 1+\mathrm{B} 2$ & 20,4 & 19,3 & $29,2 *$ & $32,6^{*}$ & $39,4^{*}$ & 10,5 & Eq. 5 & 86,8 \\
\hline B3 & 14,3 & 15,5 & 10,5 & 11,8 & 14,4 & 15,3 & Eq. 6 & NS \\
\hline $\mathrm{C}$ & 15,1 & 15,5 & $12,1^{*}$ & $11,4 *$ & $9,4^{*}$ & 7,5 & Eq. 7 & 83,3 \\
\hline
\end{tabular}

* Médias seguidas por asterisco diferem da testemunha a 5\% de probabilidade pelo teste de Dunnett; Equações: 1: $\hat{\mathrm{Y}}=7,79868 ; 2: \hat{\mathrm{Y}}=55,75653 ; 3: \hat{\mathrm{Y}}=36,44479 ; 4: \hat{\mathrm{Y}}=51,1707-0,716314^{* *} \mathrm{x}$ TM; $5: \hat{\mathrm{Y}}=20,5538+1,06300^{* *} \mathrm{x}$ TM; 6 : $\hat{Y}=13,08366 ; 7: \hat{Y}=14,8976-0,313995^{* *}$ x TM. ** Significativo a 1\% de probabilidade, pelo teste F; NS: Não significativo.

Fonte: Elaboração dos autores.

Observa-se neste estudo, que a fração B2 é a maior dentre as quatro frações que compõe os carboidratos totais. Russell et al. (1992) afirmaram que alimentos com elevado teor desta fração demandam nitrogênio não proteico para atender aos requisitos de nitrogênio dos microrganismos fermentadores de carboidratos estruturais.

Para a fração indigestível (C), foram verificados que as silagens não emurchecidas e contendo $18 \%$ de torta de mamona são similares $(\mathrm{P}>0,05)$ à silagem emurchecida, apresentando valores, respectivamente, de 37,0; 40,3 e 42,2\%. Entretanto, as silagens contendo 6 e $12 \%$ apresentaram valores $(35,0$ e $33,5 \%)$ que diferiram $(\mathrm{P}<0,05)$ da silagem emurchecida (Tabela 5). Os menores resultados verificados para as silagens contendo 6 e $12 \%$ de torta de mamona são de difícil explicação, uma vez que a fração $\mathrm{C}$ corresponde à fibra em detergente neutro indigestível (FDNi) e esta apresenta uma relação direta com o teor de lignina. Assim, o aumento das doses incrementou os teores de lignina das silagens (Tabela 4), no entanto, esperavase comportamento semelhante para a fração indigestível dos carboidratos.

Não houve ajuste de regressão para fração C dos carboidratos, apresentando média de $36,4 \%$ (Tabela 5). Assim, pode-se relatar que o aumento dos teores do coproduto ensilado promoveu a manutenção desta fração, devido à menor concentração de lignina na torta $(8,2 \%)$ em relação ao capimelefante $(10,0 \%)$ (Tabela 1$)$. Teores elevados da fração $\mathrm{C}$ nos alimentos são indesejados porque pode diminuir o consumo ou muitas vezes, limitar (replessão ruminal) com consequente diminuição do desempenho produtivo.

Avaliando o fracionamento de carboidratos e compostos nitrogenados de genótipos de capimelefante aos 56 dias de rebrota (LIMA et al., 2008), verificaram que a silagem confeccionada com o cultivar Napier apresentou valores para as frações A+B1, B2 e C de 4,3; 79,0 e 16,6\%, respectivamente. Já para a variedade Cameroon, os valores 
verificados foram, respectivamente, de 5,5;82,0 e $12,5 \%$. No entanto, Pires et al. (2009) avaliando o fracionamento de carboidratos e proteínas de silagens de capim-elefante com casca de café, farelo de cacau ou farelo de mandioca, verificaram que a silagem de capim-elefante cultivar Napier ( 80 dias de rebrota) apresentou teores de 16,6; 68,9 e $14,5 \%$ para as respectivas frações dos carboidratos $(\mathrm{A}+\mathrm{B} 1, \mathrm{~B} 2, \mathrm{C})$. Diante do exposto, verifica-se que o perfil das frações dos carboidratos é muito variável, estando correlacionado com a variedade da planta, o cultivar, a época de corte e as condições climáticas. Com isso, o fracionamento de carboidratos dos alimentos representa ferramenta fundamental para elaboração de dietas mais eficientes com o intuito de obter melhores resultados produtivos.

Em relação às frações proteicas, verificouse para o nitrogênio não proteico (Fração A) das silagens, não emurchecida ou contendo $6 \%$ de torta de mamona, teores semelhantes $(\mathrm{P}>0,05)$ ao da silagem de capim-elefante emurchecido, enquanto que os tratamentos com 12 e $18 \%$ deste coproduto apresentaram valores inferiores ao tratamento testemunha (emurchecido) (Tabela 5). Verificouse que a inclusão de doses crescentes de torta de mamona na forragem de capim-elefante provocou uma redução $(\mathrm{P}<0,01)$ linear nos teores da fração A (Tabela 5). Assim, para cada unidade de torta adicionada à forragem no momento da ensilagem, houve redução de 0,71 unidades percentuais desta fração.

À medida que incluem teores crescentes de torta de mamona à forragem no momento da ensilagem, os teores de nitrogênio amoniacal foram diminuindo (Tabela 2), o que, possivelmente, inferiu em menor teor de nitrogênio não proteico com a inclusão do coproduto ao ensilado. Os teores médios da fração A, estimados pela equação de regressão para as silagens contendo $0,6,12$ ou $18 \%$ de torta de mamona, foram de 51,2; 46,9; 42,6 e 38,3, respectivamente. Contudo, a diferença percentual entre a menor e a maior dose foi de $25,2 \%$.
As frações B1 e B2, neste estudo, foram consideradas como uma única fração $(B 1+B 2)$ e se referemàs proteínas solúveise insolúveisverdadeiras, com média velocidade de degradação. Observou-se que a silagem não emurchecida apresentou menor teor desta fração e foi, estatisticamente, semelhante $(\mathrm{P}>0,05)$ à silagem emurchecida, apresentando valores, respectivamente, de 19,3 e 20,4\%. Já as silagens contendo 6,12 ou $18 \%$ de torta de mamona foram diferentes $(\mathrm{P}<0,05)$ da silagem não emurchecida, sendo verificados os respectivos valores 29,2; 32,6 e 39,4\% (Tabela 5).

Verificou-se efeito linear crescente para a fração B1+B2 a partir da inclusão de doses de torta de mamona (Tabela 5), sendo que, para cada unidade percentual do coproduto adicionada ao ensilado, houve aumento de 1,06 unidades percentuais na fração B1+B2. Mediante equação pode-se estimar para as silagens contendo $0,6,12$ ou $18 \%$ de torta de mamona, valores para à fração supracitada, respectivamente, de 20,6;26,9; 33,3 e 39,7\%. Diante dos resultados, fica evidente que a adição deste coproduto ao capim-elefante contribuiu no aumento da fração B1+B2, o que confere, às essas silagens, melhor valor proteico.

A fração A é composta de aminoácidos, peptídeos e nitrogênio não proteico, sendo de disponibilidade imediata no rúmen. Desta maneira, percebe-se que, dentre as frações proteicas das silagens estudadas, o maior percentual é composto pela fração A, seguida das frações B1+B2 (média degradação). Desta maneira, em relação à nutrição de ruminantes, torna-se necessária a inclusão de fontes de carboidratos de rápida degradação ruminal para favorecer sincronização entre energia e proteína, maximizando a síntese de proteína microbiana (VALADARES FILHO, 2000).

A fração proteica B3 é considerada como uma fração digerível, porém é caracterizada pela lenta degradação no rúmen, uma vez que está associada à parede celular. Contudo, verificou-se que as silagens não emurchecidas, contendo 6,12 ou $18 \%$ de torta 
de mamona, não diferiram $(\mathrm{P}>0,05)$ da silagem emurchecida (Tabela 5). Assim, pode-se dizer que as diferentes doses do coproduto não influenciaram na fração B3, muito embora isso possa ser atribuído ao menor teor de nitrogênio insolúvel em detergente ácido da torta de mamona (8,6\%), em relação ao capimelefante $(29,9 \%)$ (Tabela 1). Independentemente da dose de torta de mamona utilizada, verificou-se teor médio de 13,08\% para fração B3.

Diante dos resultados verificados nas frações A, B1+B2 e B3, pode-se afirmar que a maior parte da proteína contida nas silagens é degradada no rúmen, uma vez que menores frações de B3 foram verificadas e esta grande parte escapa à degradação ruminal, por apresentar uma reduzida taxa de degradação, passando a ser digerida no intestino delgado, caracterizando-a como proteína não degradada no rúmen.

A silagem não emurchecida não diferiu $(\mathrm{P}>0,05)$ da silagem emurchecida, apresentando valores, respectivamente, de 15,1 e $15,5 \%$, no entanto, as silagens contendo 6,12 ou $18 \%$ de torta de mamona diferiram $(\mathrm{P}<0,05)$ da silagem emurchecida, sendo verificados os respectivos valores de 12,$1 ; 11,4$ e 9,4\% para a fração C (Tabela 5). Então, a inclusão da torta de mamona conferiu benefícios ao capimelefante, sobretudo, pela redução da fração C. Este fato pode ser atribuído à diminuição nos teores de NIDA, que o coproduto proporcionou à medida que teores crescentes do mesmo foram adicionados ao ensilado (Tabela 3).

Verificou efeito linear decrescente na fração $C$ (Tabela 5), sendo que para cada unidade de torta de mamona adicionada à forragem no momento da ensilagem, houve uma diminuição de 0,31 unidades percentuais da fração C. Contudo, variações deste tipo são indicativas para utilizar este coproduto na ensilagem, pois desta maneira disponibiliza-se mais proteína potencialmente degradável.

Lima et al. (2008), avaliando o fracionamento de carboidratos e compostos nitrogenados de genótipos de capim-elefante aos 56 dias de rebrota, verificaram que a silagem confeccionada com o cultivar Napier apresentou os seguintes teores para as frações proteicas, A, B1+B2, B3 e $\mathrm{C}$, respectivamente: 32,$8 ; 40,6 ; 21,4$ e 5,3\% para a variedade Cameroon, os teores observados foram, respectivamente, de 39,$2 ; 37,4 ; 17,2$ e $6,2 \%$. No entanto, Pires et al. (2009), avaliando o fracionamento de carboidratos e proteínas de silagens de capim-elefante com casca de café, farelo de cacau ou farelo de mandioca, verificaram que a silagem de capim-elefante cultivar Napier (80 dias de rebrota) apresentou teores para as frações proteicas A, B1+B2, B3 e C, respectivamente, de: 42,$9 ; 38,4 ; 10,7$ e $8,0 \%$, respectivamente. Diante do exposto, observouse que o perfil das frações proteicas é variável, estando em função do cultivar, da época de corte e das condições climáticas. Assim, o fracionamento de proteína é de fundamental importância na elaboração de dietas mais eficientes, uma vez que a proteína é um nutriente que, geralmente, mais onera o custo da dieta, bem como o conhecimento destas frações possibilita a escolha de alimentos proteicos de alta qualidade para compor as dietas dos animais.

\section{Conclusões}

A torta de mamona destaca-se como um bom aditivo na ensilagem de capim-elefante, por reduzir a umidade e melhorar o perfil fermentativo das silagens, além disso, foi eficiente em incrementar o teor de proteína bruta das silagens, principalmente quando se utiliza a dose de $18 \%$.

\section{Referências}

ALMEIDA, C. H. T.; AMORIM, H.; CASTELLETTI, C. E. M.; PERES, S. Caracterização dos coprodutos do processamento do biodiesel de mamona para geração de energia térmica e elétrica. In: CONGRESSO DA REDE BRASILEIRA DE TECNOLOGIA DE BIODIESEL, 1., 2006, Brasília. Anais... Brasília: MCT/ABIPTI, 2006. p. 68-72.

ASSOCIATION OF OFFICIAL ANALYTICAL CHEMISTS - AOAC. Official methods of analysis. $16^{\text {td }}$ ed. Arlington: AOAC, v. 2, 1995. 1094 p. 
CARVALHO, G. G. P.; GARCIA, R.; PIRES, A. J. V.; DETMANN, E.; PEREIRA, O. G.; FERNANDES, F. E. P. Degradação ruminal de silagem de capim-elefante emurchecido ou com diferentes níveis de farelo de cacau. Revista Brasileira de Zootecnia, Viçosa, MG, v. 37, n. 8, p. 1347-1354, 2008.

CARVALHO, G. G. P.; GARCIA, R.; PIRES, A. J. V.; PEREIRA, O. G.; FERNANDES, F. E. P.; OBEID, J. A.; CARVALHO, B. M. A. Fracionamento de carboidratos de silagem de capim-elefante emurchecido ou com farelo de cacau. Revista Brasileira de Zootecnia, Viçosa, MG, v. 36, n. 4, p. 1000-1005, 2007.

CARVALHO, S.; RODRIGUES, M. T.; BRANCO, R. H.; RODRIGUES, C. A. F. Consumo de nutrientes, produção e composição do leite de cabras da raça Alpina alimentadas com dietas contendo diferentes teores de fibra. Revista Brasileira de Zootecnia, Viçosa, MG, v. 35, n. 3, p. 1154-1161, 2006.

CASALI, A. O.; DETMANN, E.; VALADARES FILHO, S. C.; PEREIRA, J. C.; HENRIQUES, L. T.; FREITAS, S. G.; PAULINO, M. F. Influência do tempo de incubação e do tamanho de partículas sobre os teores de compostos indigestíveis em alimentos e fezes bovinas obtidos por procedimentos in situ. Revista Brasileira de Zootecnia, Viçosa, MG, v. 37, n. 2, p. 335-342, 2008.

CUNNIFF, P. Official methods of analysis of AOAC international. $16^{\text {td }}$ ed. Arlington: AOAC International, v. 1, 1995. $57 \mathrm{p}$.

FERRARI JÚNIOR, E.; LAVEZZO, W. Qualidade da silagem de capim-elefante (Pennisetum purpureum Schum.) emurchecido ou acrescido de farelo de mandioca. Revista Brasileira de Zootecnia, Viçosa, MG, v. 30, n. 5, p. 1424-1431, 2001.

HALL, M. B. Challenges with non-fiber carbohydrate methods. Journal of Animal Science, Champaign, v. 81, n. 12, p. 3226-3232, 2003.

JOBIM, C. C.; NUSSIO, L. G.; REIS, R. A.; SCHMIDT, P. Avanços metodológicos na avaliação da qualidade da forragem conservada. Revista Brasileira de Zootecnia, Viçosa, MG, v. 36, p. 101-119, 2007. Suplemento 0.

LICITRA, G.; HERNANDEZ, T. M.; VAN SOEST, P. J. Standardization of procedures for nitrogen fracionation of ruminant feed. Animal Feed Science Technological, Amsterdam, v. 57, n. 4, p. 347-358, 1996.

LIMA, E. da S.; SILVA, J. C. da; VÁSQUEZ, H. M.; ARAÚJO, S. A. C.; ROCHA, T. C.; COSTA, D. P. B. Fracionamento de carboidratos e compostos nitrogenados de genótipos de capim-elefante aos 56 dias de rebrota. Revista Brasileira de Zootecnia, Viçosa, MG, v. 37, n. 11, p. 1928-1933, 2008.
McDONALD, P.; HERDERSON, A. R.; HERSON, S. J. E. The biochemistry of silage. 2. ed. Malow: Chalcomble Publications, 1991.

MERTENS, D. R. Gravimetric determination of amylasetreated neutral detergent fiber in feeds with refluxing in beakers or crucibles: collaborative study. Journal of Association Official Analytical Chemists International, v. 85, n. 6, p. 1217-1240, 2002.

NATIONAL RESEARCH COUNCIL - NRC. Nutrient requeriments of dairy cattle. 7. ed. Washington D.C.: National Academy Press, 2001. 289 p.

NOCEK, J. E. In situ and other methods to estimate ruminal protein and energy digestibility: a review. Journal of Dairy Science, Madison, v. 71, n. 8, p. 20512069, 1988.

OLIVEIRA, A. S. Co-produtos da extração de óleo de sementes de mamona e girassol na alimentação de ruminantes. 2008. Tese (Doutorado em Zootecnia) Universidade Federal Viçosa, Viçosa, MG.

PELL, A. N.; SCHOFIELD, P. Computerized monitoring of gas production to measure forage digestion in vitro. Journal of Dairy Science, Madison, v. 76, n. 9, p. 10631073, 1993.

PINHO, B. D.; PIRES, A. J. V.; RIBEIRO, L. S. O.; CARVALHO, G. G. P. Ensilagem de capim-elefante com farelo de mandioca. Revista Brasileira de Saúde Produção Animal, Salvador, v. 9, n. 4, p. 641-651, 2008.

PIRES, A. J. V.; CARVAlHO, G. G. P.; GARCIA, R.; CARVALHO JUNIOR, J. N.; RIBEIRO, L. S. O.; CHAGAS, D. M. T. Capim-elefante ensilado com casca de café, farelo de cacau ou farelo de mandioca. Revista Brasileira de Zootecnia, Viçosa, MG, v. 38, n. 1, p. 3439, 2009.

PIRES, M. M.; ALVES, J. M.; ALMEIDA NETO, J. A.; ALMEIDA, C. M.; SOUSA, G. S.; CRUZ, R. S.; MONTEIRO, R.; LOPES, B. S.; ROBRA, S. Biodiesel de mamona: uma avaliação econômica. In: CONGRESSO BRASILEIRO DE MAMONA, 1., 2004, Campina Grande. Anais... Campina Grande: [s.n], 2004.

RIBEIRO JÚNIOR, J. I. Análises estatísticas no SAEG: sistema de análises estatísticas e genéticas. Viçosa: UFV, 2001. $301 \mathrm{p}$.

RODRIGUES, P. H. M.; BORGATTI, L. M. O.; GOMES, R. W.; PASSINI, R.; MEYER, P. M. Efeito da adição de níveis crescentes de polpa cítrica sobre a qualidade fermentativa e o valor nutritivo da silagem de capimelefante. Revista Brasileira de Zootecnia, Viçosa, MG, v. 34, n. 4, p. 1138-1145, 2005.

RUSSELL, B. J.; O’CONNOR, J. D.; FOX, D. J.; VAN 
SOEST, P. J.; SNIFFEN, C. J. A net carbohydrate and protein system for evaluation cattle diets: ruminal fermentation. Journal of Animal Science, Champaign, v. 70, n. 12, p. 3551-3581, 1992.

SILVA, D. J.; QUEIROZ, A. C. Análise de alimentos: métodos químicos e biológicos. Viçosa: UFV, 2002. 235

p.

SNIFFEN, C. J.; O'CONNOR, D. J.; Van SOEST, P. J.; FOX, D. G.; RUSSEL, J. B. A net carbohydrate and protein system for evaluating cattle diets: carbohydrate and protein availability. Journal of Dairy Science, Madison, v. 70, n. 11, p. 3562-3577, 1992.

VALADARES FILHO, S. C. Nutrição, avaliação de alimentos e tabelas de composição de alimentos para bovinos. In: REUNIÃO ANUAL DA SOCIEDADE BRASILEIRA DE ZOOTECNIA, 37., 2000, Viçosa, MG. Anais... Viçosa, MG: Sociedade Brasileira de Zootecnia, 2000. p. 267.
VAN SOEST, P. J.; WINE, R. H. The use of detergents in analysis of fibrous feeds: iv. Determination of plant cell-wall constituents. Journal of Association Official Analytical Chemists International, Ithaca, NY: ComstockCornell University Press, v. 50, p. 50-55, 1967.

VILELA, D. Utilização do capim-elefante na forma de forragem conservada. In: SIMPÓSIO SOBRE CAPIMELEFANTE, 1990, Coronel Pacheco. Anais... Coronel Pacheco: EMBRAPA - Centro Nacional de Pesquisa de Gado de Leite, 1990. p. 89-131.

WEISS, W. P.; CONRAD, H. R.; PIERRE, N. R. S. A theoretically based model for predicting total digestible nutrient values of forages and concentrates. Animal Feed Science and Technology, Amsterdam, v. 39, p. 95-110, 1992. 